\title{
Harbor seal diet in northern Puget Sound: implications for the recovery of depressed fish stocks
}

\author{
Monique M. Lance ${ }^{1, *}$, Wan-Ying Chang ${ }^{2}$, Steven J. Jeffries ${ }^{1}$, Scott F. Pearson ${ }^{3}$, \\ Alejandro Acevedo-Gutiérrez ${ }^{4}$
}

\begin{abstract}
${ }^{1}$ Washington Department of Fish and Wildlife, Wildlife Science Program, Lakewood, Washington 98498, USA
${ }^{2}$ National Science Foundation, Arlington, Virginia 22230, USA

${ }^{3}$ Washington Department of Fish and Wildlife, Wildlife Research Program, Olympia, Washington 98501, USA

${ }^{4}$ Department of Biology, Western Washington University, Bellingham, Washington 98225-9160, USA
\end{abstract}

\begin{abstract}
Recovery of severely declining resource stocks often leads to enforced quotas or reduced human access to those resources. Predators, however, do not recognize such restrictions and may be attracted to areas of increased prey abundances where human extraction is being limited. Such targeting by predators may reduce or retard the potential recovery of depressed stocks. In the San Juan Islands, northern Puget Sound, USA, marine reserves were implemented to recover depressed fish populations. We examine the role of harbor seals Phoca vitulina in the San Juan Islands food web. We describe the temporal and spatial variability in their diet, emphasizing species for which reserves were established (rockfish Sebastes spp.) and other important depressed stocks, including salmon Oncorhynchus spp. and Pacific herring Clupea pallasii. During winter and spring, seals primarily consumed Pacific herring, Pacific sand lance Ammodytes hexapterus, northern anchovy Engraulis mordax, and walleye pollock Theragra chalcogramma. During summer/fall, adult salmonids composed $>50 \%$ of the diet and were particularly important in oddnumbered calendar years, when pink salmon O. gorbuscha spawn. Rockfish were not a primary prey species at any time of the year, suggesting that the abundance of alternative prey species may reduce predation pressure and provide a critical buffer to rockfish predation. The importance of considering increased visitation by marine predators to areas where potential prey are enhanced through restrictions on human extractions should be considered when modeling the efficacy of quotas and reduced access areas, such as marine reserves.
\end{abstract}

KEY WORDS: Harbor seal · Phoca vitulina · Marine reserves · Diet composition · Scat analysis · Pacific herring $\cdot$ Salmon $\cdot$ Rockfish

\section{INTRODUCTION}

A history of overfishing, pollution, coastal development, and habitat loss has impacted fish populations worldwide, with general consensus by fisheries experts that ineffective management is the fundamental cause of fish declines (Milazzo 1998, Murray et al. 1999, Caddy \& Seijo 2005). Within Puget Sound, USA, stocks of Pacific herring Clupea pallasii, salmonids Oncorhynchus spp., codfish (gadids), and rock- fish Sebastes spp. have declined primarily due to overfishing (US Federal Register 2007, Gaydos \& Brown 2009, Palsson et al. 2009, Judge 2011). Currently, Puget Sound/Georgia Basin distinct population segments of yelloweye rockfish Sebastes ruberrimus and canary rockfish $S$. pinniger are listed under the US Endangered Species Act as threatened, and bocaccio rockfish $S$. paucispinis are listed as endangered under the US Endangered Species Act (US Federal Register 2010). 'Endangered' species are 
likely to become extinct without conservation actions, and 'threatened' species are likely to become endangered without conservation measures. Three additional rockfishes (brown rockfish $S$. auriculatus, copper rockfish $S$. caurinus, and quillback rockfish $S$. maliger) are considered federal species of concern, and the remaining 7 species found in the area are listed as species of concern by the State of Washington (Palsson et al. 2009). Species of concern are species about which federal and/or state agencies have concerns regarding population/stock status and threats but for which insufficient information is available to indicate a need to list the species under the Federal Endangered Species Act. State listing is typically consistent with federal listing status (Washington Administrative Code 2003, US Federal Register 2006). Rockfish are predators on fish, crab, and shrimp and are also important prey for lingcod, other marine fishes, marine mammals, and seabirds (Palsson et al. 2009). Continued declines of these fish populations, which are part of regional food webs and have both recreational and commercial value, has prompted concern by fishers, fisheries managers, and conserva- tionists and confirmed the need for ecosystem-level recovery strategies (West 1997, Gaydos \& Brown 2009).

Innovative management strategies are utilized worldwide to halt or reverse the declining trend of economically and ecologically valuable fish populations. One such approach is the establishment of marine protected areas together with changes in fisheries management practices. The goal of marine protected areas is to conserve marine resources or unique habitats and ecosystems by limiting human activities. Marine reserves are a special type of marine protected area that provide complete protection from all extractive and destructive activities (Lubchenco et al. 2003) and are intended, among other things, to protect habitat and recover depleted stocks of exploited species. Recovery efforts for rockfish in the San Juan Islands in northern Puget Sound (Fig. 1) include reducing fishing pressure and the creation of 5 marine reserves closed to all shellfish and bottom fish harvest and 8 voluntary bottom fish recovery zones where fishers are asked, but not required by law, to avoid fishing in these recovery zones (Palsson et al. 2009).

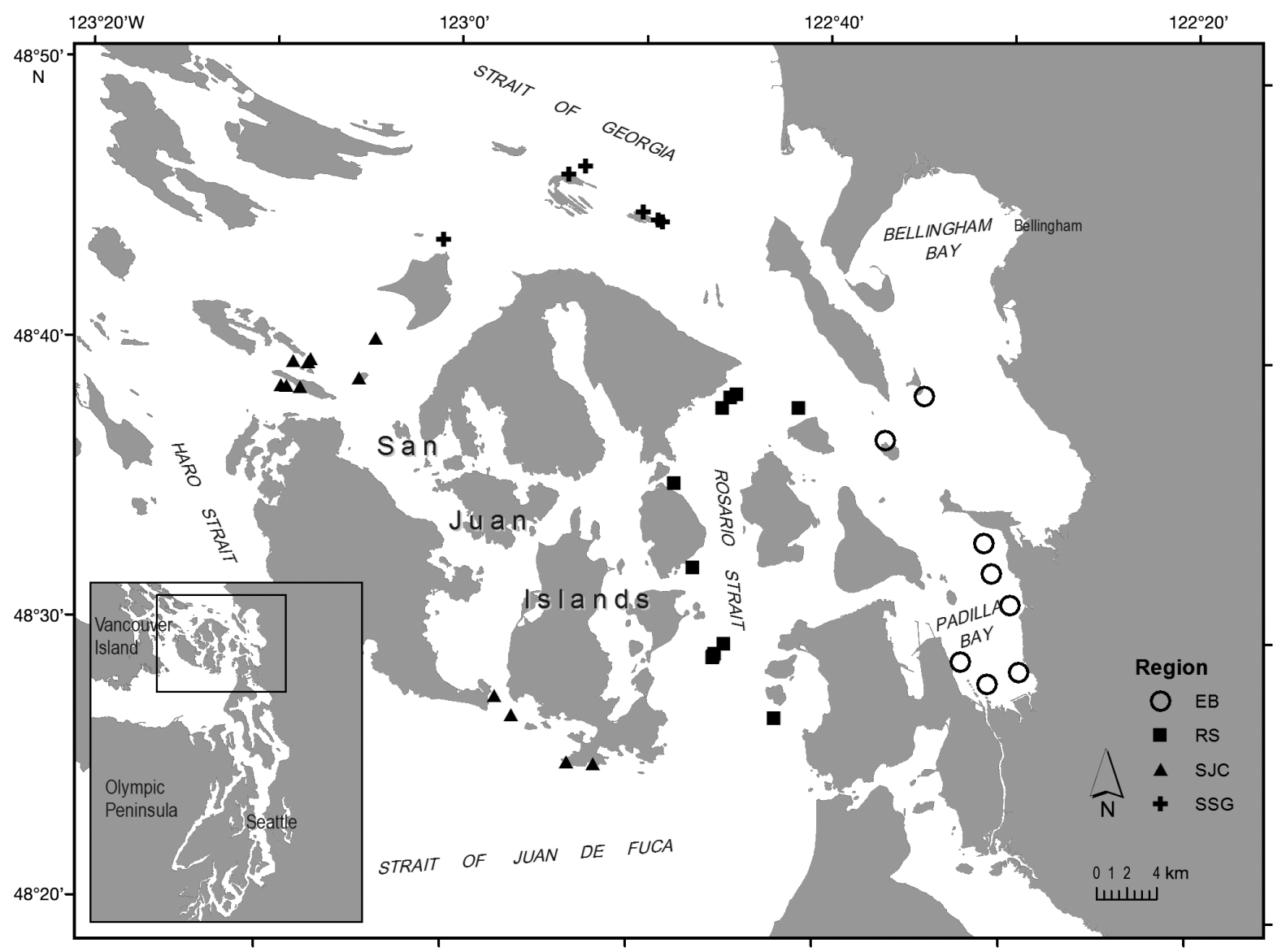

Fig. 1. San Juan Islands, Washington, USA. Symbols indicate where harbor seal scats were collected in (EB) Eastern Bays, (RS) Rosario Strait, (SJC) San Juan Channel and (SSG) Southern Strait of Georgia 
Protection from fishing can lead to increased abundance, size, and reproductive potential of prey within protected areas (Palsson 1998); however, such increases may be reduced if predators respond to areas with higher prey availability (Eisenhardt 2001, Shears \& Babcock 2002, Fanshawe et al. 2003, Middlemas et al. 2006). Pinnipeds (seals, sea lions, and walruses) are abundant, top-level predators that may limit the recovery of depressed fish stocks (Bundy 2001, Fu et al. 2001, Trzcinski et al. 2006) and have the potential to reduce the abundance of recreationally and commercially important fish species that would otherwise be available to fisheries (Stenson et al. 1997, Sharples et al. 2009). Pinnipeds may also compete with fisheries in specific regions at particular times of the year (Harwood \& Croxall 1988, Bowen et al. 1993, Fu et al. 2001, Bjørge et al. 2002). Along the west coast of North America, fish consumption by pinnipeds has increased as pinniped population size has exponentially increased after the establishment of the US Marine Mammal Protection Act of 1972 (Baraff \& Loughlin 2000, Jeffries et al. 2003, Brown et al. 2005). Consequently, temporally and spatially explicit information on predator diets is essential to evaluate the effectiveness of marine reserves in improving the abundance of reduced fish stocks and reducing the potential impacts of marine predators (Fu et al. 2001).

Harbor seals are the most abundant pinniped species in all of Puget Sound and the most common pinniped in the San Juan Islands (Jeffries et al. 2000). They are primarily piscivorous, feeding on a variety of locally and seasonally available fish and invertebrate species; however, their diet is typically dominated by a few species (Olesiuk 1993, Wright et al. 2007). The generalist diet of harbor seals allows us to investigate temporal and spatial changes in their foraging ecology and assess the relative consumption of depressed fish stocks and commercially and recreationally important fish species.

Given that pinnipeds worldwide consume fish species that have commercial or recreational value (Harwood \& Croxall 1988, Bowen et al. 1993, Fu et al. 2001, Bjørge et al. 2002) and given that harbor seals are generalists that consume species that are also targeted by fisheries on the west coast of North America (Orr et al. 2004, Thomas et al. 2011), it is possible that harbor seals also prey on rockfish, a recreationally important genus. If harbor seals prey on rockfish, the seals may be attracted to the San Juan Islands marine reserves that were established to recover this depressed fish genus. To assess this possibility, the spatial use of marine reserves by harbor seals and the predation risk to rockfish were examined in 2 companion studies (Ward et al. 2012, Peterson et al. 2012). In the present study, we examine harbor seal consumption of depressed and/or recreationally and commercially important fish stocks in areas adjacent to marine reserves. Specifically, we (1) describe the seasonal diet of harbor seals in the San Juan Islands, (2) assess temporal and spatial predation on depressed fish stocks by harbor seals, and (3) assess the age and size of fish consumed and the degree of prey specialization.

\section{MATERIALS AND METHODS}

\section{Study area and sample processing}

The San Juan Islands $\left(48^{\circ} 33^{\prime} \mathrm{N}, 123^{\circ} 00^{\prime} \mathrm{W}\right.$; Fig. 1), Washington, USA, is an area characterized by hundreds of islands, rocky intertidal outcrops, and rich marine life. Harbor seals in this area use $>130$ haulouts, including intertidal sandbars, small islands, and rocky reefs (Jeffries et al. 2000). An estimated 6500 to 8700 seals haul-out in the San Juan Islands and Eastern Bays (Jeffries et al. 2003, Hardee 2008).

Fecal samples (scats) were collected seasonally over 3 collection periods: March to early June ('spring'), late July to September ('summer/fall'), and January to February ('winter') during 4 consecutive years, 2005 to 2008. Scats were collected from 23 haul-out locations during daytime low tides. The sites were dispersed throughout the study area (Fig. 1), represented various habitat types used by harbor seals, were the largest haul-outs where we could collect adequate sample sizes, and were easily accessible by boat. Sample collection locations were placed into 4 sampling regions based on habitat type and harbor seal foraging ecology data defined as 'Eastern Bays', 'Rosario Strait', 'San Juan Channel', and 'Southern Strait of Georgia' (Fig. 1; Hardee 2008). A total of 2 or 3 collection trips were conducted each season, with a target sample size of 60 scats per season per region as recommended by Trites \& Joy (2005). Samples were stored frozen.

In the laboratory, scat samples were enclosed in fine mesh paint-strainer bags and cleaned using a washing machine to remove organic material and retain prey hard parts (Orr et al. 2003) or nested sieves if samples contained rocks (Lance et al. 2001). Hard parts were cleaned (i.e. flesh removed) and stored dry. Cephalopod beaks and cartilaginous parts were stored in isopropyl alcohol to prevent distortion for subsequent identification and measuring. 
Prey were identified to the lowest possible taxon using a dissecting microscope, reference fish bone collections from Washington and Oregon, and published fish bone, otolith, and cephalopod beak keys (Morrow 1979, Wolff 1982, Clarke 1986, Cannon 1987, Harvey et al. 2000). Otoliths were measured using an ocular micrometer and graded based on observed erosion (Tollit et al. 1997, 2004). We present data as percent frequency of occurrence. To gain insights into seasonal diet variation, the frequencies were weighted by the numbers of seals present in each region in the spring and summer/fall (estimates from Hardee 2008). Winter counts were not available, and we assumed the winter seal population was equal to the spring population. We also assumed that the regional population for each season remained constant over the period 2005 to 2008 . These assumptions are reasonable given that harbor seal populations have been stable since the mid-1990s (Jeffries et al. 2003).

\section{Diet composition}

Fish species from fecal samples were placed into 11 non-overlapping prey groups based on taxonomy and observed unweighted occurrence frequencies $>5 \%$ within a given season. These groups are clupeids, adult salmonids Oncorhynchus spp., Pacific sand lance Ammodytes hexapterus, northern anchovy Engraulis mordax, gadids, juvenile salmonids, sculpins Cottus spp., shiner surfperch Cymatogaster aggregata, rockfish Sebastes spp., and cephalopods. Taxonomic resolution (species vs. family or genus) was based on resolution of the prey remains. We included the category 'other' for all remaining prey species with unweighted occurrence frequencies $<5 \%$. Rockfish were included as a prey group despite an overall low occurrence frequency because of conservation interest and the objectives of the present study. Diet diversity was based on the number of prey groups per fecal sample. Diet was modeled against season, region and year using generalized linear models (GENMOD, in SAS version 9.1.3). Likelihood ratio statistics for Type 3 analyses were used to identify statistically significant factors. For factors with more than 2 levels, additional contrast statements were included to compare contributions to frequency of occurrence between each pair of levels. Interaction terms were considered between significant main factors and were included in the model only when the added terms substantially improved the model fit based on Akaike information criterion values. Adult salmon, clupeids, sand lance, gadids, cottids, and 'other' were the 6 prey groups that had sufficient occurrence data for this analysis. For these diet groups, we utilized the subset of all years' spring and summer/fall data from Eastern Bays, San Juan Channel, and Southern Strait of Georgia. Rosario Strait data were excluded because of insufficient spring and winter data. For occurrence of rockfish in the diet, we excluded Rosario Strait data and data from the winter of 2006 and merged San Juan Channel and Southern Strait of Georgia samples to form a new region so that most of the winter data remain in the analysis (Table 1). San Juan Channel and Southern Strait of Georgia data were combined due to their low sample sizes and ecological similarities, including deep-channel systems and prey assemblages. For the occurrence of adult salmonids, only summer/fall samples were included because most adult salmon return to spawn during this season, and $>96 \%$ of occurrences of adult salmon in the diet occurred during summer/fall.

\section{Prey group associations}

To investigate dietary specialization as well as associations of different prey species in diets of individual seals, we compared the mean number of observed prey groups per scat among seasons for

Table 1. Number of harbor seal scats collected in the San Juan Islands from 2005 to 2008 by season and region (total sample $=1683$ scats). Number in parentheses indicates number of samples that either did not contain prey remains $(n=11)$ or samples containing only non-identified prey remains $(n=29)$ and neither are included in the Total. $\mathrm{Sp}=$ spring, $\mathrm{SF}=$ summer/fall, $\mathrm{W}=$ winter

\begin{tabular}{|lccccc|}
\hline Collection dates & $\begin{array}{c}\text { Eastern } \\
\text { Bays }\end{array}$ & $\begin{array}{c}\text { Rosario } \\
\text { Strait }\end{array}$ & $\begin{array}{c}\text { San Juan } \\
\text { Channel }\end{array}$ & $\begin{array}{c}\text { Southern Strait } \\
\text { of Georgia }\end{array}$ & Total \\
\hline Sp 2005 & 4 & 0 & 42 & 31 & 77 \\
SF 2005 & $57(1)$ & $127(1)$ & 119 & 79 & 382 \\
W 2006 & 0 & 11 & 32 & 3 & 46 \\
Sp 2006 & 17 & $3(1)$ & 67 & 9 & 96 \\
SF 2006 & $49(2)$ & 43 & $110(1)$ & $34(2)$ & 236 \\
W 2007 & $29(1)$ & $5(4)$ & $18(1)$ & 2 & 54 \\
Sp 2007 & $50(1)$ & 1 & 37 & 8 & 96 \\
SF 2007 & 105 & $56(1)$ & $174(3)$ & $70(3)$ & 405 \\
W 2008 & 18 & 1 & $14(1)$ & 2 & 35 \\
Sp 2008 & 44 & $2(1)$ & 32 & $8(5)$ & 86 \\
SF 2008 & $52(2)$ & 26 & 55 & $37(9)$ & 170 \\
Total & 425 & 275 & 700 & 283 & 1683 \\
\hline
\end{tabular}


each region using a Kruskal-Wallis test. We applied a cluster analysis (hclust, in R version 2.7.1) to explore and illustrate associations between groups. This analysis was carried out by season for all years combined. For a given season, the gamma coefficient (Goodman \& Kruskal 1954) was calculated for each pair of indicators of the occurrence of the corresponding prey groups, and '1 - gamma' was used to define the dissimilarity matrix for the cluster analysis. A dissimilarity value closer to zero between a pair of prey groups indicated that the 2 groups were more likely to occur together in a given scat sample.

\section{Prey size and age}

Otoliths recovered in scats were classified by side (left and right) and condition (good and fair) for fishlength analysis. Measured otolith length was transformed to fish length by applying published speciesspecific regression equations (Harvey et al. 2000). To avoid double counting, either the right or left side subset was chosen based on whichever yielded the larger sample. To prevent single scats over-biasing a sample collection, we only considered the sample size sufficient for analysis if there were at least 5 otolith-containing scat samples in each combination of season and year. Only otoliths in good condition were included. Analysis of variance $F$-tests were used to compare the means of derived fish length by season and year. A regional comparison of derived fish length was only possible for a few species due to limited sample sizes. Pacific herring Clupea pallasii, in spring and summer/fall, and walleye pollock Theragra chalcogramma, in summer/fall, were the only species and times with adequate sample sizes for fish-length analysis.

For Pacific herring Clupea pallasii, in addition to the fish-length analysis based on otoliths in good condition, we estimated the age classes consumed by harbor seals by season. Two age classes, adult and juvenile, were considered, and the age class assignment was determined based on a new fish-length measure utilizing grade-specific correction factors so that otoliths in both good and fair condition could be included. We used a 3-step procedure. First, we estimated the lengths of herring consumed based on the measured otolith lengths of a single subset (left or right otoliths) using a published species-specific regression equation (Harvey et al. 2000). Second, we applied grade-specific length correction factors ( $g$ $\mathrm{LCFs}$ ) to the estimated herring lengths to correct for digestion erosion. g-LCFs are proven to dramatically improve the accuracy of size estimates of fish consumed by pinnipeds based on otoliths in scats (Tollit et al. 2004, Phillips \& Harvey 2009); however, species specific $\mathrm{g}$-LCFs were not available for herring. We therefore used the difference between the published average length correction factor (a-LCF) for herring (Harvey 1989) and that of the closely related species Pacific sardine Sardinops sagax (Phillips \& Harvey 2009) to generate g-LCFs for herring using the following equation for each otolith grade:

$\mathrm{g}-\mathrm{LCF}_{\mathrm{h} i}=100 /\left[100-\% \mathrm{SLR}_{i} \times\left(\mathrm{a}-\mathrm{LCF}_{\mathrm{h}} / \mathrm{a}-\mathrm{LCF}_{\mathrm{s}}\right)\right]$

where $i$ represents the otolith grade ('good' or 'fair'), $\mathrm{g}-\mathrm{LCF}_{\mathrm{h}}$ is the calculated grade-specific length correction factor for herring, \%SLR is the percent sardine length reduction for grade $i$ from Phillips \& Harvey (2009), and the a-LCF ${ }_{s}$ and $a-L_{C F}$ are the average length correction factors for sardine and herring, respectively (Thomas et al. 2011). Lastly, we calculated herring age classes consumed by harbor seals by comparing our estimated herring lengths to size-at-age data for Pacific herring in the Southern Strait of Georgia (J. Schweigert unpubl. data). This was the closest surveyed stock to our San Juan Islands study area. Juvenile herring were differentiated from adults as those with an estimated age class $<3$ (Hay 1985, Gustafson et al. 2006). We modeled the probability of consumed herring being juvenile using generalized linear models.

\section{RESULTS}

\section{Diet composition}

We collected 1723 harbor seal scat samples in the San Juan Islands. Only 11 scats contained no fish, cephalopod or invertebrate remains (hereafter 'empty'), and 29 contained non-identifiable prey parts (very small bone fragments) and were excluded from further analysis. A total of 46 fish and 4 cephalopod species were found in harbor seal scat samples. The most common prey were Pacific herring Clupea pallasii (hereafter herring) and Pacific sand lance Ammodytes hexapterus (hereafter sand lance), occurring year round, and adult salmon, prevalent in summer/fall (Table 2, Fig. 2). Based on abundance in the area, the 'herring species' group was most likely Pacific herring, and the 'gadids' group was most likely walleye pollock Theragra chalcogramma. Salmon bones were not identifiable to species without genetic techniques; thus, the prey group 'adult salmon' was composed of an unknown proportion of 
Table 2. Frequency of occurrence of prey types (\%) in harbor seal scats from the San Juan Islands. Samples were collected from haulouts between 2005 and 2008. Sample counts of occurrence are weighted by estimated regional harbor seal population counts by season: (S/F) summer/fall, (Sp) spring, and (W) winter. Taxa are arranged from highest to lowest frequency of occurrence among and within prey groups. Unident. = unidentified

\begin{tabular}{|c|c|c|c|c|c|}
\hline Prey group & Group or species & Common name & $\begin{array}{c}\mathrm{S} / \mathrm{F} \\
(\mathrm{n}=1193)\end{array}$ & $\begin{array}{c}\mathrm{W} \\
(\mathrm{n}=135)\end{array}$ & $\begin{array}{c}\text { Sp } \\
(\mathrm{n}=355)\end{array}$ \\
\hline \multirow[t]{4}{*}{ Clupeids } & Clupea pallasii & Pacific herring & 28.74 & 38.84 & 63.05 \\
\hline & Unident. clupeids & Herrings & 17.51 & 16.05 & 7.76 \\
\hline & Alosa sapidissima & American shad & 0.76 & 2.84 & 2.49 \\
\hline & Sardinops sagax & Sardine & 0.25 & 0.16 & - \\
\hline \multirow[t]{6}{*}{ Salmonids-adult } & Unident. salmonids & Salmon & 51.37 & 8.99 & 4.16 \\
\hline & Oncorhynchus gorbuscha & Pink salmon & 2.00 & - & - \\
\hline & Oncorhynchus kisutch & Coho salmon & 1.60 & - & - \\
\hline & Oncorhynchus keta & Chum salmon & 1.59 & - & - \\
\hline & Oncorhynchus nerka & Sockeye salmon & 0.81 & 2.25 & - \\
\hline & Oncorhynchus tshawytscha & Chinook salmon & 0.58 & - & - \\
\hline Sand lance & Ammodytes hexapterus & Pacific sand lance & 16.06 & 32.83 & 25.02 \\
\hline Anchovy & Engraulis mordax & Northern anchovy & 1.19 & 17.50 & 10.22 \\
\hline \multirow[t]{5}{*}{ Gadids } & Theragra chalcogramma & Walleye pollock & 12.19 & 8.80 & 13.23 \\
\hline & Unident. gadids & Codfishes & 7.30 & 13.96 & 15.03 \\
\hline & Merluccius productus & Pacific hake & 1.07 & 5.20 & 6.78 \\
\hline & Microgadus proximus & Pacific tomcod & 0.41 & 0.92 & 0.63 \\
\hline & Gadus macrocephalus & Pacific cod & 0.08 & - & - \\
\hline \multirow[t]{4}{*}{ Salmonids-juvenile } & Unident. salmonids & Salmon & 11.58 & 0.73 & 1.09 \\
\hline & Oncorhynchus tshawytscha & Chinook salmon & 4.75 & 0.73 & 1.56 \\
\hline & Oncorhynchus kisutch & Coho salmon & 0.20 & - & - \\
\hline & Oncorhynchus nerka & Sockeye salmon & 0.08 & - & - \\
\hline \multirow[t]{4}{*}{ Cottids } & Unident. cottids & Sculpins & 2.57 & 7.74 & 11.27 \\
\hline & Leptocottus armatus & Pacific staghorn sculpin & 4.59 & 3.23 & 1.83 \\
\hline & Hemilepidotus spp. & Irish lords & 2.46 & 5.89 & 0.61 \\
\hline & Aspicottus bison & Buffalo sculpin & 0.05 & - & - \\
\hline Surf perch & Cymatogaster aggregata & Shiner surfperch & 2.89 & 6.87 & 4.09 \\
\hline \multirow[t]{3}{*}{ Rockfish } & Unident. scorpaenids & Rockfish (age unknown) & 2.75 & 5.43 & 3.55 \\
\hline & Unident. scorpaenids (adult) & Rockfish (adult) & 0.22 & - & 0.80 \\
\hline & Unident. scorpaenids (juvenile) & Rockfish (juvenile) & 0.13 & - & - \\
\hline \multirow[t]{23}{*}{ Other } & Squalus acanthias & Spiny dogfish & 0.96 & 13.10 & 1.24 \\
\hline & Unident. liparidids & Snailfishes & 0.42 & 12.08 & 5.81 \\
\hline & Unident. rajids & Skates & 1.94 & 10.68 & 8.29 \\
\hline & Unident. zoarcids & Eelpouts & 4.52 & 0.86 & 1.19 \\
\hline & Unident. pleuronectids & Righteye flounders & 2.76 & 3.00 & 5.10 \\
\hline & Gasterosteus aculeatus & Threespine stickleback & 0.96 & 2.56 & 6.21 \\
\hline & Unident. pholids & Gunnels & 1.83 & 0.57 & 0.85 \\
\hline & Porichthys notatus & Plainfin midshipman & 1.79 & 0.65 & 2.21 \\
\hline & Unident. petromyzontids & Lampreys & 1.72 & - & - \\
\hline & Unident. osmerids & Smelts & 1.38 & 0.77 & 0.66 \\
\hline & Pleuronectes vetulus & English sole & 1.30 & - & 0.19 \\
\hline & Hypomesus pretiosus & Surf smelt & 1.11 & - & 0.36 \\
\hline & Platichthys stellatus & Starry flounder & 0.76 & 3.34 & \\
\hline & Thaleichthys pacificus & Eulachon & 0.70 & 0.10 & 1.05 \\
\hline & Hexagrammid species & Greenlings & 0.46 & 0.82 & 0.75 \\
\hline & Diaphus theta & California headlight fish & 0.50 & 0.10 & 0.57 \\
\hline & Anarrhichthys ocellatus & Wolf eel & 0.32 & - & - \\
\hline & Cryptacanthodes giganteus & Giant wrymouth & 0.31 & - & - \\
\hline & Microstomus pacificus & Dover sole & 0.27 & 0.41 & - \\
\hline & Unident. bothids & Lefteye flounders & 0.23 & 0.41 & - \\
\hline & Unident. stichaeids & Pricklebacks & 0.23 & 0.10 & - \\
\hline & Unident. shrimp & Shrimp & 0.20 & - & - \\
\hline & Ronquilus jordani & Northern ronquil & 0.16 & 0.41 & - \\
\hline
\end{tabular}


Table 2 (continued)

\begin{tabular}{|c|c|c|c|c|c|}
\hline Prey group & Group or species & Common name & $\begin{array}{c}\mathrm{S} / \mathrm{F} \\
(\mathrm{n}=1193)\end{array}$ & $\begin{array}{c}\mathrm{W} \\
(\mathrm{n}=135)\end{array}$ & $\begin{array}{c}\text { Sp } \\
(\mathrm{n}=355)\end{array}$ \\
\hline \multirow{16}{*}{ Cephalopods } & Isopsetta isolepis & Butter sole & 0.08 & - & - \\
\hline & Unident. crustaceans & Crustaceans & 0.08 & - & - \\
\hline & Errex zachirus & Rex sole & 0.04 & - & - \\
\hline & Unident. bothids/pleuronectids & Flatfish & 0.04 & & \multirow{4}{*}{0.44} \\
\hline & Stenobrachius leucopsarus & Northern lampfish & - & 0.41 & \\
\hline & Unident. argentinids & Argentines & - & 0.82 & \\
\hline & Scomber japonicus & Chub mackerel & - & 0.41 & \\
\hline & Ophiodon elongatus & Lingcod & - & - & 0.28 \\
\hline & Psettichthys melanostictus & Sand sole & - & - & 0.10 \\
\hline & Octopus rubescens & Pacific red octopus & 1.69 & 1.95 & 5.33 \\
\hline & Berryteuthis magister & Magister armhook squid & 1.76 & 0.91 & 0.91 \\
\hline & Gonatus onyx & Clawed armhook squid & 0.17 & 1.02 & 5.18 \\
\hline & Loligo opalescens & Market squid & 0.71 & 0.82 & 1.13 \\
\hline & Loligo spp. & & - & 0.32 & - \\
\hline & Gonatus spp. & & 0.12 & - & - \\
\hline & Unident. cephalopods & Cephalopods & 0.30 & 0.92 & 0.75 \\
\hline
\end{tabular}

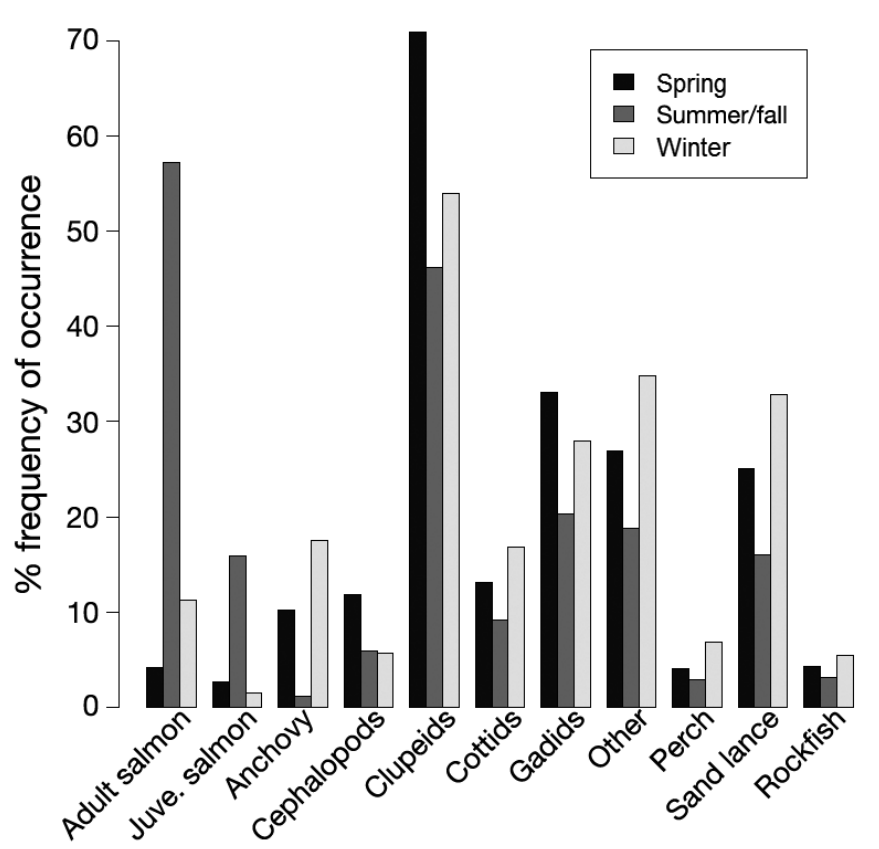

Fig. 2. Weighted frequency of occurrence of prey species in harbor seal scat samples by season from 2005 to 2008. Juve = juvenile

the salmon species present in the area. Other important but less abundant dietary components included gadids and cottids consumed year-round, juvenile salmon consumed in the summer/fall, and northern anchovy (hereafter anchovy), spiny dogfish Squalus acanthias, snailfish (liparidids), and skate (rajids). consumed during winter and spring (Table 2).

\section{Season, region, and interannual comparisons}

Overall, the mean number of prey species found per sample was 1.98. Our data indicated significant seasonal differences in diet diversity for San Juan Channel and Southern Strait of Georgia. The mean numbers of prey species per sample for San Juan Channel were 1.84, 1.96, and 2.72 for summer/fall, spring, and winter, respectively. Southern Strait of Georgia followed a similar pattern, with 1.47, 1.68, and 2.43 for summer/fall, spring, and winter, respectively. The combined mean numbers of prey species for all seasons combined for Eastern Bays and Rosario Strait were 2.25 and 2.11, respectively.

Results from the generalized linear models indicate that seasonal patterns of prey consumed varied among years and sampling regions (Fig. 3, Table 3). For clupeids, there were differences relative to Region, Year, Season, and Region $\times$ Season, with Season being the most influential factor (Table 3). Spring had higher occurrences, Southern Strait of Georgia had lower occurrences, and 2007 had higher occurrences than 2005 and 2006. Year, Region, and Year $\times$ Region differed for adult salmon (Table 3). In years in which pink salmon Oncorhynchus gorbuscha were present, 2005 and 2007, San Juan Channel showed higher occurrences than other regions. Pink salmon otoliths were the most frequently identified salmon otolith, but few salmon otoliths were recovered and identifiable to species level (Table 2). Season, Year, and Region differed for sand lance, with Region being the most influential factor. San Juan Channel had higher 


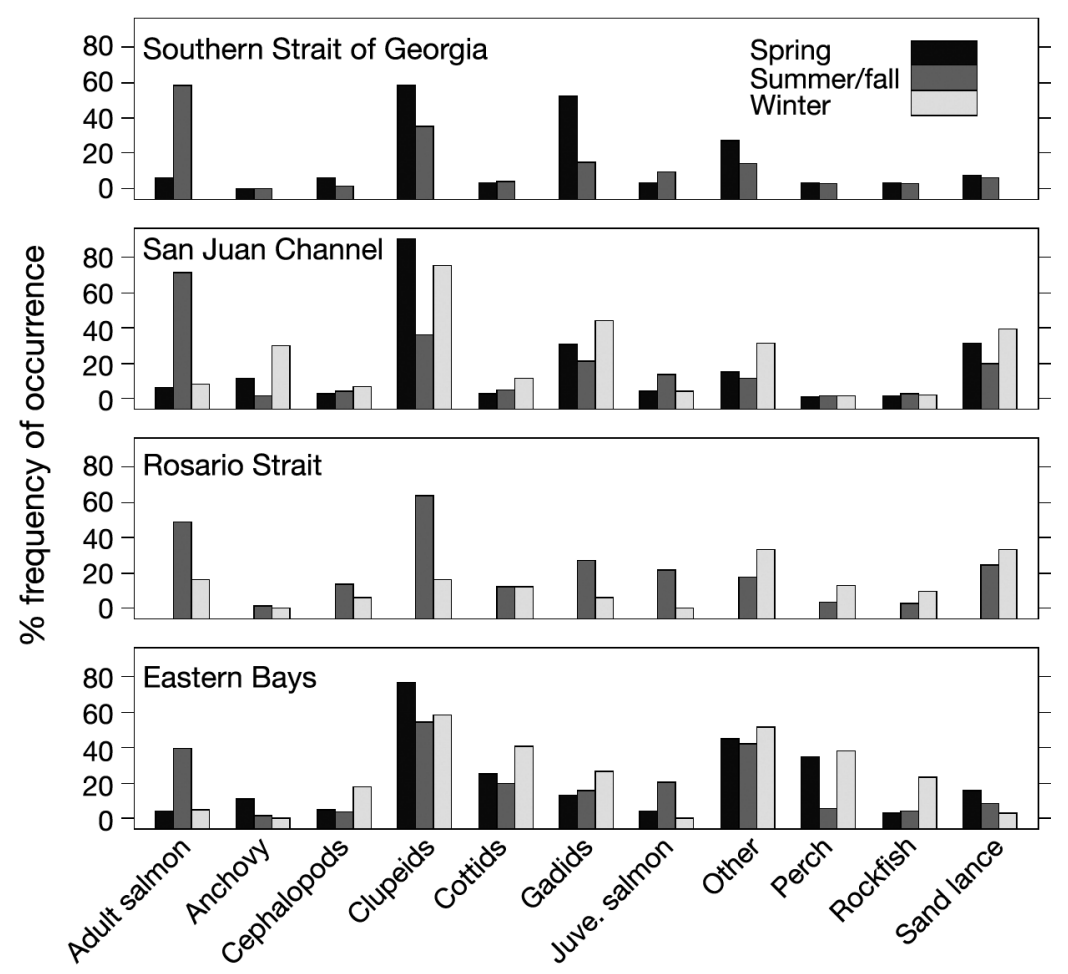

Fig. 3. Weighted frequency of occurrence of prey groups in harbor seal scats for each season by region. Juve. = juvenile occurrences of sand lance than Eastern Bays and Southern Strait of Georgia, and Spring and 2008 had higher occurrence frequencies than the other seasons or years, respectively. For gadids, Year, Season, and Year $\times$ Season differed, with highest occurrences in 2005 and 2007 during spring. For cottids, there were regional and yearly differences. Eastern Bays had higher occurrences than San Juan Channel and Southern Strait of Georgia. For rockfish, there were regional and seasonal effects, with Eastern Bays having higher occurrences than other regions and spring having lower occurrences of rockfish in general. This regional difference was driven by the unusually high frequency of rockfish occurrence for winter 2007 Eastern Bay samples. If winter data are removed, then there are no significant differences among regions (Eastern Bays vs. other) and between seasons (summer/fall vs. spring). Subadult

Table 3. Region, season, and year differences among prey groups. Significant contrasts show differences in frequency of occurrence among levels within each factor. Regions: EB = Eastern Bays, RS = Rosario Strait, SJC = San Juan Channel, SSG = Southern Strait of Georgia; years: 2005 to 2008; seasons: Winter, Spring, Summer/Fall

\begin{tabular}{|c|c|c|c|c|c|}
\hline Prey group & $\begin{array}{l}\text { Significant } \\
\text { factor }\end{array}$ & $\begin{array}{c}\text { Type } 3 \\
\text { chi-squared }\end{array}$ & $\mathrm{p}$ & df & Significant contrast \\
\hline Clupeids & $\begin{array}{c}\text { Region } \\
\text { Year } \\
\text { Season } \\
\text { Region } \times \text { Season }\end{array}$ & $\begin{array}{c}22.51 \\
59.02 \\
110.61 \\
38.28\end{array}$ & $\begin{array}{l}<0.0001 \\
<0.0001 \\
<0.0001 \\
<0.0001\end{array}$ & $\begin{array}{l}2 \\
3 \\
1 \\
2\end{array}$ & $\begin{array}{l}\text { EB, SJC > SSG } \\
2007>2005,2006 \\
\text { Spring > Summer/Fall } \\
\text { Summer/Fall: EB > SJC, SSG; Spring: SJC > EB > SSG }\end{array}$ \\
\hline Adult salmonids & $\begin{array}{c}\text { Year } \\
\text { Region } \\
\text { Year } \times \text { Region }\end{array}$ & $\begin{array}{l}56.78 \\
66.20 \\
24.96\end{array}$ & $\begin{array}{c}<0.0001 \\
<0.0001 \\
0.003\end{array}$ & $\begin{array}{l}3 \\
3 \\
9\end{array}$ & $\begin{array}{l}2005>2006,2007,2008 ; 2007>2008 \\
\text { SJC > EB, RS, SSG; SSG > EB } \\
\text { 2005: SJC > RS; 2006: SJC, SSG > EB, RS; } \\
\text { 2007: SJC > EB, SSG, RS > EB; 2008: SJC, SSG > EB }\end{array}$ \\
\hline Sand lance & $\begin{array}{l}\text { Season } \\
\text { Year } \\
\text { Region }\end{array}$ & $\begin{array}{c}9.79 \\
19.27 \\
54.15\end{array}$ & $\begin{array}{r}0.0018 \\
0.0002 \\
<0.0001\end{array}$ & $\begin{array}{l}1 \\
3 \\
2\end{array}$ & $\begin{array}{l}\text { Spring }>\text { Summer/Fall } \\
2008>2005,2006,2007 \\
\text { SJC }>\text { EB, SSG }\end{array}$ \\
\hline Gadids & $\begin{array}{c}\text { Season } \\
\text { Year } \\
\text { Year } \times \text { Season }\end{array}$ & $\begin{array}{c}22.71 \\
23.09 \\
103.05\end{array}$ & $\begin{array}{l}<0.0001 \\
<0.0001 \\
<0.0001\end{array}$ & $\begin{array}{l}1 \\
3 \\
3\end{array}$ & $\begin{array}{l}\text { Spring }>\text { Summer/Fall } \\
2005>2006,2007,2008 ; 2007>2008 \\
\text { Spring }>\text { Summer/Fall for 2005, 2007; Spring < Summer/ } \\
\text { Fall for } 2008\end{array}$ \\
\hline Cottids & $\begin{array}{l}\text { Year } \\
\text { Region }\end{array}$ & $\begin{array}{l}11.68 \\
68.87\end{array}$ & $\begin{array}{r}0.0086 \\
<0.0001\end{array}$ & $\begin{array}{l}3 \\
2\end{array}$ & $\begin{array}{l}2008>2007>2005 \\
\text { EB }>\text { SJC, SSG }\end{array}$ \\
\hline Rockfish & $\begin{array}{l}\text { Region } \\
\text { Season }\end{array}$ & $\begin{array}{c}6.74 \\
20.76\end{array}$ & $\begin{array}{r}0.0094 \\
<0.0001\end{array}$ & $\begin{array}{l}1 \\
2\end{array}$ & $\begin{array}{l}\text { EB }>\text { Other regions } \\
(\text { Winter, Summer/Fall) }>\text { Spring }\end{array}$ \\
\hline Other & $\begin{array}{c}\text { Year } \\
\text { Region }\end{array}$ & $\begin{array}{l}20.56 \\
121.1\end{array}$ & $\begin{array}{r}0.0001 \\
<0.0001\end{array}$ & $\begin{array}{l}3 \\
2\end{array}$ & $\begin{array}{l}2006,2008>2005,2007 \\
\text { EB > SJC, SSG }\end{array}$ \\
\hline
\end{tabular}



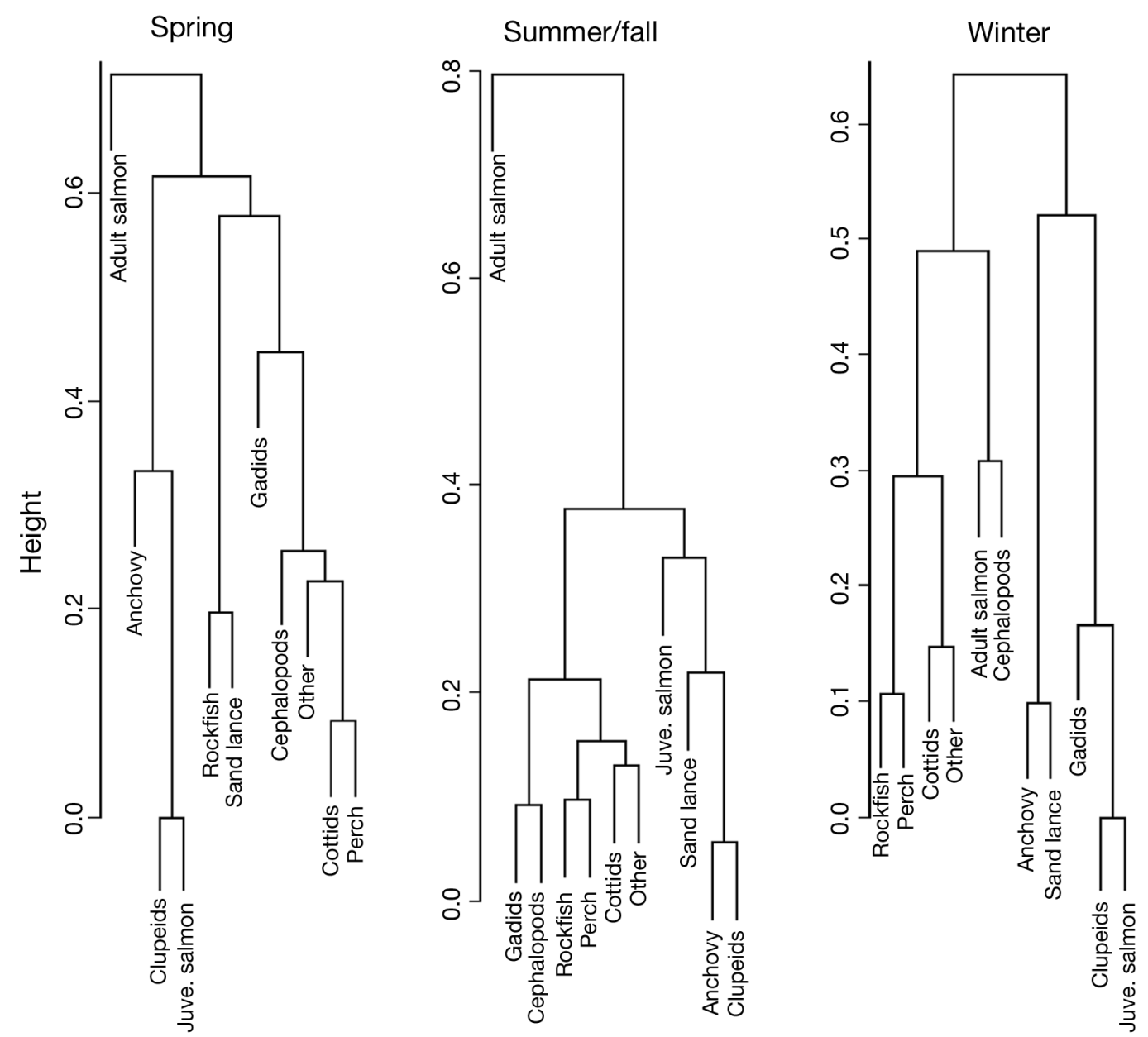

Fig. 4. Prey group associations in harbor seal scat samples illustrated in hierarchical clustering dendrograms by season. Juve. $=$ juvenile

(ages 2 to 4 yr) and adult (ages 6 to $>8$ yr) rockfish otoliths were recovered in 16 samples, but species identification using otoliths was possible in only 4 cases. Two samples contained Puget Sound rockfish Sebastes emphaeus otoliths, one sample most likely contained age 2 yelloweye rockfish, and one sample most likely contained age 2 black rockfish $S$. melanops. Year and Region differed for the prey group 'other'. The non-pink salmon years, 2006 and 2008, had higher 'other' occurrences; Eastern Bays had higher 'other' occurrences than San Juan Channel and Southern Strait of Georgia.

\section{Prey group associations}

The maximum number of prey species identified in a single scat was 11 . The number of prey groups per scat sample was highest in winter for San Juan Channel $(p<0.0001)$ and Southern Strait of Georgia $(p=$
0.0479). Hard parts recovered from scats indicate that harbor seal prey species were not randomly distributed, given that some prey species were consistently found together (Fig. 4). Clusters formed during summer/fall and appear to fall into 3 fairly distinct groups: (1) adult salmon, (2) small schooling forage fishes (clupeids, anchovy, and sand lance) as well as juvenile salmon, and (3) a mixture of non-schooling fish species (cottids, some rockfishes, most species in the 'other' prey group), cephalopods, and looseschooling fish species (gadids and perch). During winter, 2 distinct groups were very similar to summer/fall: (1) small schooling forage fishes (clupeids, anchovy, and sand lance) as well as juvenile salmon and walleye pollock and (2) a mixture of nonschooling fish species. These 2 prey groups were generally true for spring as well. For all seasons, the dendrograms illustrate that seals appeared to consume either schooling bait fish or pursue fish individually (Fig. 4). 
Table 4. Frequency of Pacific herring Clupea pallasii otolith by age class for spring and summer/fall seasons

\begin{tabular}{|c|c|c|c|c|c|c|}
\hline \multirow{2}{*}{ Year } & \multicolumn{3}{|c|}{ Spring } & \multirow[b]{2}{*}{ Sample size } & \multirow{2}{*}{$\begin{array}{l}\text { Summer/Fall } \\
\text { Juvenile (\%) }\end{array}$} & \multirow[b]{2}{*}{ Adult (\%) } \\
\hline & Sample size & Juvenile (\%) & Adult (\%) & & & \\
\hline 2005 & 83 & 16.87 & 86.75 & 187 & 72.73 & 48.13 \\
\hline 2006 & 107 & 0.93 & 99.07 & 132 & 25.00 & 76.52 \\
\hline 2007 & 55 & 32.73 & 67.74 & 123 & 33.33 & 66.07 \\
\hline 2008 & 25 & 0.00 & 100 & 13 & 61.54 & 38.46 \\
\hline
\end{tabular}

\section{Prey size and age}

Mean herring length varied relative to year (Type 3 $F=6.73, \mathrm{df}=3, \mathrm{p}=0.0002$ ), season (Type $3 F=64.03$, $\mathrm{df}=1, \mathrm{p}<0.0001$ ), and the interaction Season $\times$ Year (Type $3 F=7.97$, df $=3, \mathrm{p}<0.0001$ ). Spring had higher mean lengths than summer/fall. Year 2006 had higher mean lengths than 2007 and 2008, but there were only seasonal differences (spring > summer/fall) for 2005 and 2008. We found no summer/fall pollock otolith differences among years.

The proportion of juvenile herring consumed differed among seasons (Type 3 chi-squared $=73.40$, $\mathrm{df}=1, \mathrm{p}<0.0001$ ) and years (Type 3 chi-squared $=$ 62.96, df $=3, \mathrm{p}<0.0001$ ), and there was a Season Year interaction (Type 3 chi-squared $=41.61$, df $=3$, $\mathrm{p}<0.0001$ ). Higher proportions of juveniles were found in the diet during summer/fall compared to spring for all years except for 2007, when similar proportions were observed among seasons (Table 4).

\section{DISCUSSION}

\section{Seasonal diet of harbor seals in the San Juan Islands}

Seals fed on species that are seasonally and regionally abundant, with a high proportion of adult salmon in the summer, herring year-round, and sand lance, anchovy, and juvenile walleye pollock during winter and spring. Except for adult salmon, all of these species are small $(<10 \mathrm{~cm})$, schooling, energy-rich fishes (Van Pelt et al. 1997, Anthony et al. 2000). Seals switched from a diet dominated by herring and sand lance in the winter and spring to a diet dominated by adult salmon in the summer/fall, coinciding with an increase in adult salmon spawning abundance (Tables 2-4, Figs. 2-4). The higher occurrences of adult salmon in 2005 and 2007 occurred in years when, according to test fisheries, an estimated 2.9 and 6.6 million pink salmon, respectively, entered the Strait of Juan de Fuca and swam through the San Juan Islands bound primarily for the Fraser River in southern British Columbia (Pacific Salmon Commission, www.psc.org). In contrast, adult salmon occurrences were lower in the diet in 2006 and 2008, when no pink salmon were recorded in the area (Pacific Salmon Commission, www.psc.org). Other harbor seal studies also document opportunistic feeding on seasonally and regionally abundant species with a high frequency of small, schooling forage fishes (Olesiuk 1993, Browne et al. 2002, Wright et al. 2007).

Herring, sand lance, anchovy, and pollock are key members of the forage fish food web in the San Juan Islands and support higher-trophic fish, seabirds, and marine mammals (Olesiuk 1993, Suryan \& Harvey 1998, Lance \& Thompson 2005). All of these fish species spawn during late winter and early spring, when they also peaked in harbor seal diet (Pedersen \& DiDonato 1982, Therriault et al. 2002, Penttila 2007). Harbor seals consumed primarily spawning adult herring during spring and juveniles during summer/ fall. Herring spawning aggregations are an important seasonal resource pulse for a wide variety of predators, including pinnipeds (Hourston \& Haegele 1980, Lassuy 1989, Willson \& Womble 2006, Therriault et al. 2009). Consistent with our results, harbor seal consumption of adult herring peaked during spawn season in the north Atlantic (Andersen et al. 2007). In contrast, harbor seals on Protection Island (46 km SW of our study area) did not respond to spawning herring pulses and consumed primarily juveniles during spring, which was attributed primarily to juvenile abundance, the relative ease of capture of juveniles, and the decrease in energy density of adult herring during spawning (Thomas et al. 2011). Our results may differ because the number of spawning areas and magnitude of spawning is greater in the San Juan Islands than at Protection Island (Stick \& Lindquist 2009), thereby increasing the likelihood that seals would respond to such a prey pulse. For pollock, harbor seals may be focusing on aggregations of spawning adults as well as large 
schools of young-of-the-year fish because they were abundant in the area during our scat sampling (Wildermuth et al. 2008).

Prey associations were not randomly distributed. In general, individuals either preyed on seasonally available large prey, like salmon or schools of small prey, or pursued individual ground fish. For example, spawning adult salmon peak in abundance in the summer/fall (Quinn 2005) and had near exclusive presence in the diet at that time (Fig. 4), a result that has been documented elsewhere (e.g. Scordino 2010). Prey group associations may have also been influenced by habitat types in close proximity to haul-out sites. For example, the concentration of species associated with nearshore environments during the spring (cottids and perch) and winter (cottids and 'other') reflects the close proximity of these habitats to particular haul-out sites. Finally, associations of prey within a given scat may reflect specialized foraging techniques of individual harbor seals and/or high foraging site fidelity in response to availability, habitat type, and behavior of their prey. Specialized foraging techniques relative to prey type and its behavior are documented for the San Juan Islands, Protection Island, and elsewhere (Suryan \& Harvey 1998, Zamon 2001, Bowen et al. 2002). At the same time, fidelity to foraging sites is consistent with other research suggesting that individual seals travel repeatedly to specific locations to consume reliable and concentrated prey (Suryan \& Harvey 1998, Tollit et al. 1998, Thomas et al. 2011, Peterson et al. 2012).

\section{Potential for impact on depressed fish stocks}

Herring are abundant in northern Puget Sound, and in the present study, they were the primary prey species for harbor seals year-round. At least 25 vertebrate species in addition to harbor seals forage on relatively large numbers of spawning herring and/or herring eggs (Lassuy 1989, Willson \& Womble 2006, Anderson et al. 2009). In our study, seals during spring primarily consumed spawning adults, when herring form dense aggregations (Lassuy 1989, Stick \& Lindquist 2009). It is unclear if seals alone limit herring stocks; it is possible that a combination of factors including seal predation affect herring recovery, similar to the influence of grey seals Halichoerus grypus on Atlantic cod Gadus morhua recovery (Fu et al. 2001, MacKenzie et al. 2011).

Puget Sound chinook salmon Oncorhynchus tshawytscha and steelhead O. mykiss are both federally threatened species under the US Endangered Spe- cies Act (US Federal Register 2007, Gaydos \& Brown 2009, Judge 2011). No steelhead otoliths were identified from the harbor seal scat samples. We observed few chinook otoliths, and we suggest that harbor seal predation on listed Puget Sound chinook salmon and steelhead was likely buffered by the overwhelming abundance of other salmon species, namely pink salmon $O$. gorbuscha and sockeye salmon $O$. nerka, that occur in the area during the summer/fall. Identification of salmon species in diet via quantitative fatty acid signature analysis (Iverson et al. 2004) and/or DNA identification in seal scat (Tollit et al. 2009) would provide additional information on the relative proportion of each salmon species consumed.

The 3 primary codfish species in Puget Sound include Pacific hake Merluccius productus, Pacific cod Gadus macrocephalus, and walleye pollock Theragra chalcogramma; all are under review by the Washington Department of Fish and Wildlife to determine if they warrant listing as State endangered, threatened, or sensitive (Gaydos \& Brown 2009). The regional Pacific hake stock is also a federal species of concern: it has declined sharply over the past $15 \mathrm{yr}$, and the once thriving fishery is now closed (Bailey et al. 1999, Gaydos \& Brown 2009). Walleye pollock was the primary cod fish species consumed by harbor seals in the San Juan Islands, peaking in the diet during spring, when juvenile (age 0 to 1) pollock form schools and are numerous (Wildermuth et al. 2008). Consumption of juvenile pollock by harbor seals could affect overall recruitment and should be considered in recovery planning.

Predators exert top-down pressure on community structure in marine reserves (Shears \& Babcock 2002), and predation has the potential to limit rockfish recovery (Drake et al. 2010). Consequently, examining the occurrence of rockfish in seal diet is one very important metric when evaluating impacts and the ultimate ability of marine reserves to be effective at recovering rockfish. Concerns over declining rockfish populations in Puget Sound were one of the primary reasons for establishing marine reserves in the San Juan Islands. Tagged harbor seals apparently do not forage inside marine reserves in the San Juan Islands (Peterson et al. 2012). Here, we document that rockfish were a small component of seal diet. Rockfish occurred most frequently in the diet during winter, which was the season when seal diet became more diverse due to the low prevalence in winter of adult salmon. A profitable large biomass of prey like adult salmonids in the area may reduce predation pressure on rockfish and provide a 'buffer' to preda- 
tion. For example, in years when pink salmon are absent from Puget Sound (e.g. 2006 and 2008), the frequency of rockfish in seal diet is $\sim 22$-fold higher than in years when pink salmon are present (Ward et al. 2012).

Genetic and molecular techniques, including the use of DNA, stable isotopes, and fatty acid signatures, are increasingly being used to assess the diets of a variety of marine predators, including harbor seals, and can yield different answers than traditional techniques, such as scat and stomach content analyses (Smith et al. 1996, Tollit et al. 2006, Nordstrom et al. 2008, Deagle et al. 2009). A parallel study in the San Juan Islands using fatty acids confirms that salmon and herring were prevalent in seal diet but that some individual seals consume more rockfish than indicated by scat (J. Bromaghin pers. comm.). Complementary diet studies for marine mammals, which compare techniques for reconstructing diet (scats vs. molecular techniques) and test the assumption that seals may preferentially prey on soft parts of rockfish, leading to rockfish being under-represented in scat samples, will help us understand seal biology and impacts on regional fish populations.

Bioenergetics models have been constructed for a number of pinniped species to estimate prey requirements (Stenson et al. 1997, Winship et al. 2002, Trzcinski et al. 2006). Estimates of consumption of prey categories that comprise a small portion of the diet have the largest coefficients of variation (Winship et al. 2002). Thus, species with small populations and vulnerable life histories, like some rockfish in Puget Sound, may compose a minor part of the predator's diet, but the impact could potentially be great if the predation represents a very large component of total mortality for the prey species (Christensen \& Walters 2004). As a result, even 'low' biomass consumption estimates are not insignificant from a fish perspective, especially if the consumption occurs in a small area, if there are many seals, or if seals increase mortality rate of young age class fish (see Chassot et al. 2009), and this fact underscores the importance of including top predators in trophic ecosystem models, fisheries management, and recovery efforts.

\section{CONCLUSIONS}

Harbor seals are integral members of the San Juan Island ecosystem, and their role in the food web is complex. They are an abundant high-level predator that consume seasonally and regionally abundant species and, in concert with other predators, may enhance predation or reduce predation through buffering, on particular species and age classes at different times of the year and even during different years. In the present study, their diet was dominated by herring, which are small, schooling, energy-rich fish, in winter and spring and by adult salmon in summer/ fall. This seasonal variation was very likely driven by prey availability and fish spawning aggregations. Because the links within ecosystems are complicated, the recovery of single species can take a long time. Our results highlight 2 important considerations when developing fish stock recovery plans. First, recovery plans should consider season, region, and year when assessing the potential impacts of marine predators, such as harbor seals, that specialize on specific prey in specific years (e.g. every other year for pink salmon) and at particular times of the year in any given location. These plans should also consider that this complex relationship between predator and prey is also influenced by proximity to important haul-out sites and by individual seal diet specialization. Second, ecosystem models developed to inform marine ecosystem planning and recovery should include detailed predator-prey interactions because the overall effect of predation on prey is influenced by the relative abundance and population dynamics of predators and prey, the abundance and availability of other prey resources, and the cumulative reliance on prey by a suite of marine predators.

Acknowledgements. We thank J. Gould for assisting with boat operations and field collection of samples; B. Diehl, K. Luxa, K. Brock, A. Brower, A. Galloway, and M. Erkel for assistance with field collection and sample processing; W. Walker for salmon otolith and cephalopod beak species identification; $\mathrm{S}$. Riemer for rare prey species identification and reviews; J. Schweigert for use of herring survey data; W. Palsson for providing recent trawl data and reviews; J. Foisy for creating Fig. 1 ; D. Penttila and K. Stick for providing forage fish information and reviews; K. Adicks for providing regional salmon abundance data; J. Topping and S. Rosenfield for identification of rockfish otoliths; and H. Huber and J. Thomason for laboratory space. Three anonymous reviewers and the editor provided very helpful comments on an early draft. J. Gaydos, S. Peterson, A. Thomas, G. Williams, and B. Wright provided reviews and valuable input. Harbor seal research activities were conducted under MMPA Research Permit 782-1702-00. K. Ryan permitted access to intertidal areas at sites within the San Juan Islands Wildlife Refuge, and P. Green permitted access to intertidal areas of Goose Island for sample collection. Financial support was provided by The SeaDoc Society, a program of the UC Davis Wildlife Health Center, under Research Agreement No. K004431-25, the National Science Foundation Award No. 0550443 to A.A., and Washington Department of Fish and Wildlife. 


\section{LITERATURE CITED}

Andersen SM, Teilmann J, Harders PB, Hansen EH, Hjøllund D (2007) Diet of harbour seals and great cormorants in Limfjord, Denmark: interspecific competition and interaction with fishery. ICES J Mar Sci 64:1235-1245

Anderson EM, Lovvorn JR, Esler D, Boyd WS, Stick KC (2009) Using predator distributions, diet, and condition to evaluate seasonal foraging sites: sea ducks and herring spawn. Mar Ecol Prog Ser 386:287-302

Anthony JA, Roby DD, Turco KR (2000) Lipid content and energy density of forage fishes from the northern Gulf of Alaska. J Exp Mar Biol Ecol 248:53-78

Bailey KM, Quinn TJ, Bentzen F, Grant WS (1999) Population structure and dynamics of walleye pollock Theragra chalcogramma. Adv Mar Biol 37:179-255

Baraff LS, Loughlin TR (2000) Trends and potential interactions between pinnipeds and fisheries of New England and the U.S. West Coast. Mar Fish Rev 62:1-32

> Bjørge A, Bekkby T, Bakkestuen V, Framstad E (2002) Interaction between harbour seals, Phoca vitulina, and fisheries in complex coastal waters explored by combined Geographic Information System (GIS) and energetics modeling. ICES J Mar Sci 59:29-42

> Bowen WD, Lawson JW, Beck B (1993) Seasonal and geographic variation in the species composition and size of prey consumed by grey seals (Halichorerus grypus) on the Scotian Shelf. Can J Fish Aquat Sci 50:1768-1778

Bowen WD, Tully D, Boness DJ, Bulheier BM, Marshall GJ (2002) Prey-dependent foraging tactics and prey profitability in a marine mammal. Mar Ecol Prog Ser 244: 235-245

> Brown RF, Wright BE, Riemer SD, Laake J (2005) Trends in abundance and current status of harbor seals in Oregon: 1977-2003. Mar Mamm Sci 21:657-670

Browne P, Laake J, DeLong RL (2002) Improving pinniped diet analyses through identification of multiple skeletal structures in fecal samples. Fish Bull 100:423-433

Bundy A (2001) Fishing on ecosystems: the interplay of fishing and predation in Newfoundland-Labrador. Can J Fish Aquat Sci 58:1153-1167

Caddy JF, Seijo JC (2005) This is more difficult that we thought! The responsibility of scientists, managers and stakeholders to mitigate the unsustainability of marine fisheries. Philos Trans R Soc Lond B 360:59-75

Cannon DY (1987) Marine fish osteology: a manual for archaeologists. Publication no. 18. Archaeology Press, Simon Fraser University, Burnaby, BC

Chassot E, Duplisea D, Hammill M, Caskenette A, Bousquet N, Lambert Y, Stenson G (2009) Role of predation by harp seals Pagophilus groenlandicus in the collapse and non-recovery of northern Gulf of St. Lawrence cod Gadus morhua. Mar Ecol Prog Ser 379:279-297

Christensen V, Walters CJ (2004) Ecopath and Ecosim: methods, capabilities and limitations. Ecol Model 172: 109-139

Clarke MR (1986) A handbook for the identification of cephalopod beaks. Clarendon Press, Oxford

Deagle BE, Kirkwood R, Jarman SN (2009) Analysis of Australian fur seal diet by pyrosequencing prey DNA in faeces. Mol Ecol 18:2022-2038

Drake JS, Berntson EA, Cope JM, Gustafson RG and others (2010) Status review of five rockfish species in Puget Sound, Washington: bocaccio (Sebastes paucispinis), canary rockfish $(S$. pinniger), yelloweye rockfish $(S$. ruberrimus), greenstriped rockfish (S. elongatus), and redstripe rockfish ( $S$. proriger). US Dept Comm, NOAA Tech Memo, NMFS-NWFSC-108

Eisenhardt E (2001) Effect of the San Juan Islands marine preserves on demographic patterns of nearshore rocky reef fish. MSc thesis, University of Washington, Seattle, WA

Fanshawe S, Vanblaricom GR, Shelly AA (2003) Restored top carnivores as detriments to the performance of marine protected areas intended for fishery sustainability: a case study with red abalones and sea otters. Conserv Biol 17:273-283

Fu C, Mohn R, Fanning LP (2001) Why the Atlantic cod (Gadus morhua) stock off eastern Nova Scotia has not recovered. Can J Fish Aquat Sci 58:1613-1623

Gaydos JK, Brown NA (2009) Species of concern within the Salish Sea marine ecosystem: changes from 2002 to 2008. Species of Concern, Proceedings of the 2009 Puget Sound Georgia Basin Ecosystem Conference, Puget Sound Partnership and Environment Canada, Seattle, WA

Goodman LA, Kruskal WH (1954) Measures of association for cross classifications. J Am Stat Assoc 49:732-764

Gustafson RG, Drake J, Ford MJ, Myers JM, Holmes EE, Waples RS (2006) Status review of Cherry Point Pacific herring (Clupea pallasii) and updated status review of the Georgia Basin Pacific herring distinct population segment under the Endangered Species Act. US Dept Comm, NOAA Tech Memo, NMFS-NWFSC-76

Hardee S (2008) Movements and home ranges of harbor seals (Phoca vitulina) in the inland waters of the Pacific Northwest. MSc thesis, Western Washington University, Bellingham, WA

> Harvey JT (1989) Assessment errors associated with harbour seal (Phoca vitulina) faecal sampling. J Zool (Lond) 219: 101-111

Harvey JT, Loughin TR, Perez MA, Oxman DS (2000) Relationship between fish size and otolith length for 62 species of fishes from the eastern north Pacific Ocean. US Dept Comm, NOAA Tech Rep, NMFS Circ 150:1-36

Harwood J, Croxall JP (1988) The assessments of competition between seals and commercial fisheries in the North Sea and the Antarctic. Mar Mamm Sci 4:13-33

- Hay DE (1985) Reproductive biology of Pacific herring (Clupea harengus pallasii). Can J Fish Aquat Sci 42: s111-s126

Hourston AS, Haegele CW (1980) Herring on Canada's Pacific coast. Can Spec Publ Fish Aquat Sci 48

- Iverson SJ, Field C, Bowen WD, Blanchard W (2004) Quantitative fatty acid signature analysis: a new method of estimating predator diets. Ecol Monogr 74:211-235

Jeffries SJ, Gearin PJ, Huber HR, Saul DL, Pruett DA (2000) Atlas of seal and sea lion haulout sites in Washington. Washington Dept Fish Wildl, Olympia, WA

Jeffries SJ, Huber HR, Calambokidis J, Laake J (2003) Trends and status of harbor seals in Washington State: 1978-1999. J Wildl Manag 67:207-218

Judge MM (2011) 2011 implementation status assessment final report: a qualitative assessment of implementation of the Puget Sound Chinook salmon recovery plan. Lighthouse Natural Resource Consulting, Everett, WA

> Lance MM, Thompson CW (2005) Overlap in diets and foraging of Common Murres and Rhinoceros Auklets after the breeding season. Auk 122:887-901

Lance MM, Orr AJ, Riemer SD, Weise MJ, Laake JL (2001) Pinniped food habits and prey identification techniques 
protocol. AFSC Processed Rep 2001-04. Alaska Fish Sci Cent, Natl Mar Fish Serv, NOAA, Seattle, WA

Lassuy DR (1989) Species profiles: life histories and environmental requirements of coastal fishes and invertebrates (Pacific Northwest - Pacific Herring. US Fish Wildl Serv Biol Rep 82 (11.126):1-18

Lubchenco J, Palumbi SR, Gaines SD, Andelman S (2003) Plugging a hole in the ocean: the emerging science of marine reserves. Ecol Appl 13:3-7

MacKenzie BR, Margit E, Ojaveer H (2011) Could seals prevent cod recovery in the Baltic Sea? PLoS ONE 6:e18998

Middlemas SJ, Barton TR, Armstrong JD, Thompson PM (2006) Functional and aggregative responses of harbour seals to changes in salmonid abundance. Proc Biol Sci 273:193-198

Milazzo M (1998) Subsidies in world fisheries: a re-examination. World Bank Tech Pap no. 406, Fish Ser. The World Bank, Washington DC

Morrow JE (1979) Preliminary keys to the otoliths of some adult fishes of the Gulf of Alaska, Bering Sea, and Beaufort Sea. NOAA Circ Rep 420

Murray SN, Ambrose RF, Bohnsack JA, Botsford LW and others (1999) No-take reserve networks: sustaining fishery populations and marine ecosystems. Fisheries 24: $11-25$

Nordstrom CA, Wilson LJ, Iverson SJ, Tollit DJ (2008) Evaluating quantitative fatty acid signature analysis (QFASA) using harbour seals Phoca vitulina richardsii in captive feeding studies. Mar Ecol Prog Ser 360:245-263

Olesiuk PF (1993) Annual prey consumption by harbour seals (Phoca vitulina) in the Strait of Georgia, British Columbia. Fish Bull 91:491-515

Orr AJ, Laake JL, Dhruv MI, Banks AS, DeLong RL, Huber HR (2003) Comparison of processing pinniped scat samples using a washing machine and nested sieves. Wildl Soc Bull 31:253-257

Orr AJ, Banks AS, Mellman S, Huber HR, DeLong RL, Brown RF (2004) Examination of the foraging habits of Pacific harbor seal (Phoca vitulina richardsi) to describe their use of the Umpqua River, Oregon, and their predation on salmonids. Fish Bull 102:108-117

Palsson WA (1998) Monitoring the response of rockfishes to protected areas. In: Yoklavich M (ed) Marine harvest refugia for West Coast Rockfish: a workshop. NOAA Tech Memo NOAA-TM-NMFS-SWFSC-255, p 64-73

Palsson WA, Tsou T, Bargmann GG, Buckley RM and others (2009) The biology and assessment of rockfishes in Puget Sound. FPT 09-04 Washington Dept of Fish and Wildlife, Olympia, WA

Pedersen M, DiDonato G (1982) Groundfish management plan for Washington's inside waters. Progress Report No. 170. Washington Dept of Fish and Wildlife, Olympia, WA

Penttila D (2007) Marine forage fishes in Puget Sound. Puget Sound Nearshore Partnership Tech Rep 2007-03, Seattle District, US Army Corps of Engineers, Seattle, WA

Peterson SH, Lance MM, Jeffries SJ, Acevedo-Gutiérrez A (2012) Long distance movements and disjunct spatial use of harbor seals (Phoca vitulina) in the inland waters of the Pacific Northwest. PLoS ONE 7(6) e39046

> Phillips EM, Harvey JT (2009) A captive feeding study with the Pacific harbor seal (Phoca vitulina richardsii): implications for scat analysis. Mar Mamm Sci 25:373-391

Quinn TP (2005) The behavior and ecology of Pacific salmon and trout. University of Washington Press, Seattle, WA
Scordino J (2010) West coast pinniped program investigations on California sea lion and Pacific harbor seal impacts on salmonids and other fishery resources. Pacific States Mar Fish Comm, Portland, OR

Sharples RJ, Arrizabalaga B, Hammond PS (2009) Seals, sandeels and salmon: diet of harbour seals in St. Andrews Bay and the Tay Estuary, southeast Scotland. Mar Ecol Prog Ser 390:265-276

> Shears NT, Babcock RC (2002) Marine reserves demonstrate top-down control of community structure on temperate reefs. Oecologia 132:131-142

> Smith RJ, Hobson KA, Koopman HN, Lavigne DM (1996) Distinguishing between populations of fresh and saltwater harbour seals (Phoca vitulina) using stable-isotope ratios and fatty acid profiles. Can J Fish Aquat Sci 53: $272-279$

Stenson GB, Hammill MO, Lawson JW (1997) Predation by harp seals in Atlantic Canada: preliminary consumption estimates for Arctic cod, capelin and Atlantic cod. J Northwest Atl Fish Sci 22:137-154

Stick KC, Lindquist A (2009) 2008 Washington State herring stock status report. FPA 09-05, Fish Program, Washington Dept Fish Wildl, Olympia, WA

Suryan RM, Harvey JT (1998) Tracking harbor seals (Phoca vitulina richardsii) to determine dive behavior, foraging activity, and haul-out site use. Mar Mamm Sci 14:361-372

Therriault TW, McDiarmid AN, Wulff W, Hay D (2002) Review of Northern Anchovy (Engraulis mordax) biology and fisheries, with suggested management options for British Columbia. Research Document 2002/112. Fisheries and Oceans Canada, Nanaimo

Therriault TW, Hay DE, Schweigert JF (2009) Biological overview and trends in pelagic forage fish abundance in the Salish Sea (Strait of Georgia, British Columbia). Mar Ornithol 37:3-8

- Thomas AC, Lance MM, Jeffries SJ, Miner BG, AcevedoGutiérrez A (2011) Harbor seal foraging response to a seasonal resource pulse, spawning Pacific herring. Mar Ecol Prog Ser 441:225-239

Tollit DJ, Steward MJ, Thompson PM, Pierce GJ, Santos MB, Hughes S (1997) Species and size differences in the digestion of otoliths and beaks: implications for estimates of pinniped diet composition. Can J Fish Aquat Sci 54: 105-119

> Tollit DJ, Black AD, Thompson PM, Mackay A and others (1998) Variations in harbour seal (Phoca vitulina) diet and dive-depths in relation to foraging habitat. $J$ Zool (Lond) 244:209-222

Tollit DJ, Heaslip SG, Joy R, Call KA, Trites AW (2004) A method to improve size estimates of Walleye pollock (Theragra chalcogramma) and Atka mackerel (Pleurogrammus monopterygius) consumed by pinnipeds: digestion correction factors applied to bones and otoliths recovered in scats. Fish Bull 102:498-508

Tollit D, Heaslip S, Deagle B, Iverson S, Joy R, Rosen D, Trites A (2006) Estimating diet composition in sea lions: which technique to choose. In: Trites AW, Atkinson SK, DeMaster DP, Fritz LW, Gelatt TS, Rea LD, Wynne KM (eds) Sea lions of the world. Alaska Sea Grant College Program, University of Alaska, Fairbanks, AK, p 293-308

Tollit DJ, Schulze AD, Trites AW, Olesiuk PF and others (2009) Development and application of DNA techniques for validating and improving pinniped diet estimates. Ecol Appl 19:889-905 
Trites AW, Joy R (2005) Dietary analysis from fecal samples: how many scats are enough? J Mammal 86:704-712

Trzcinski MK, Mohn R, Bowen BW (2006) Continued decline of an Atlantic cod population: how important is grey seal predation? Ecol Appl 16:2276-2292

US Federal Register (2006) Endangered and threatened species: revision of species of concern list, candidate species definition, and candidate species list, Vol 71, No 200

US Federal Register (2007) Endangered and threatened species: final listing determination for Puget Sound steelhead, Vol 72, No 91

US Federal Register (2010) Endangered and threatened wildlife and plants: threatened status for the Puget Sound/Georgia Basin distinct population segments of Yelloweye and Canary rockfish and endangered status for the Puget Sound/Georgia Basin distinct population segment of Bocaccio Rockfish, Vol 75, No 81

Van Pelt TI, Piatt JF, Lance BK, Roby DD (1997) Proximate composition and energy density of some North Pacific forage fishes. Comp Biochem Physiol A 118:1393-1398

Ward EJ, Levin PS, Lance MM, Jeffries SJ, AcevedoGutiérrez A (2012) Integrating diet and movement data to identify hot spots of predation risk and areas of conservation concern for endangered species. Conserv Lett 5: $37-47$

Washington Administrative Code (2003) Endangered, threat-

Editorial responsibility: Hans Heinrich Janssen, Oldendorf/Luhe, Germany ened and sensitive wildlife species classifications: 23212-297

West JE (1997) Protection and restoration of marine life in the inland waters of Washington State. Puget Sound/ Georgia Basin Environ Rep Ser: No 6

Wildermuth DA, Stick KC, Velasquez DE (2008) Research project summary, acoustic assessment of pelagic forage in Rosario Strait, Washington, June 2008. Washington Department of Fish and Wildlife, Seattle, WA

Willson MF, Womble JN (2006) Vertebrate exploitation of pulsed marine prey: a review and the example of spawning herring. Rev Fish Biol Fish 16:183-200

Winship AJ, Trites AW, Rosen DAS (2002) A bioenergetic model for estimating the food requirements of Steller sea lions Eumetopias jubatus in Alaska, USA. Mar Ecol Prog Ser 229:291-312

Wolff G (1982) A beak key for eight eastern tropical Pacific cephalopod species with relationships between beak dimensions and size. Fish Bull 80:357-370

> Wright BE, Riemer SD, Brown RF, Ougzin AM, Bucklin KA (2007) Assessment of harbor seal predation on adult salmonids in a Pacific Northwest Estuary. Ecol Appl 17: 338-351

Zamon JE (2001) Seal predation on salmon and forage schools as a function of tidal currents in the San Juan Islands, Washington, USA. Fish Oceanogr 10:353-366

Submitted: November 28, 2011; Accepted: June 18, 2012 Proofs received from author(s): August 30, 2012 